$\begin{array}{ll}\begin{array}{l}\text { Secure sources } \\ \text { Radioactive materials } \\ \text { face tighter controls } \\ \text { after bomb threat } \\ p 776\end{array} & \begin{array}{l}\text { Shot down } \\ \text { Scientists attack } \\ \text { plans to keep missile } \\ \text { test results secret } \\ p 777\end{array}\end{array}$

\title{
US urged to provide smallpox vaccines for emergency crews
}

\section{Erika Check, Washington}

The United States looks set to widen the group of health workers and other 'first responders' who will be inoculated against smallpox, as a precaution against a possible bioterror attack.

Public-health officials argue that inoculating the larger group could serve as a much-needed clinical trial of a modern, laboratory-produced smallpox vaccine, as well as strengthening the United States' ability to contain a smallpox outbreak.

A committee that advises US health officials on immunization policies may issue new guidelines on smallpox vaccination this week. The Advisory Committee on Immunization Practices (ACIP) was due to meet in Atlanta, Georgia, on 19-20 June and, according to several experts, was likely to recommend a more extensive vaccination programme. But the experts differ on which 'first responder' groups should be vaccinated, with candidates including hospital staff, police officers and emergencyresponse teams.

The ACIP's present recommendation is that only a small group of health workers who have to handle viruses related to smallpox be vaccinated. But many observers say that the committee is set to change its

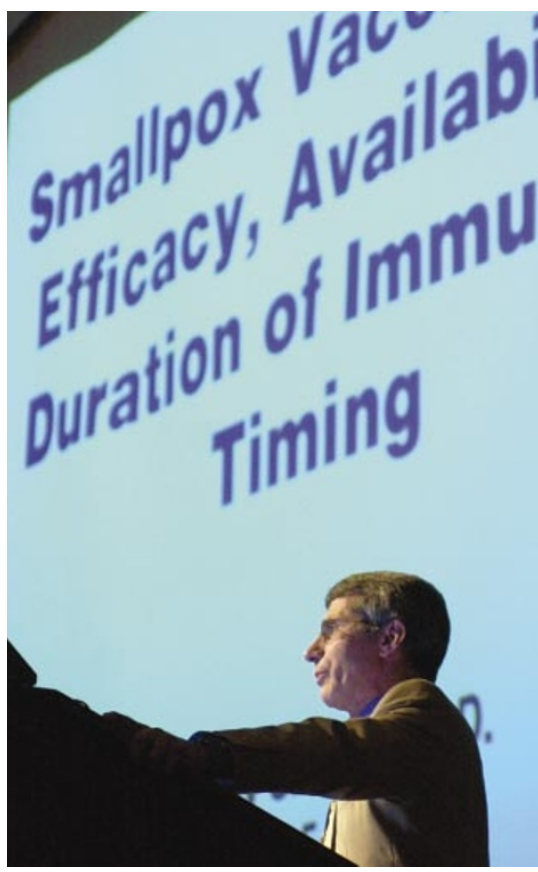

Shot in the arm: Anthony Fauci anticipates a widening of the smallpox vaccination programme.

advice after consultation with scientists, including a public discussion organized on

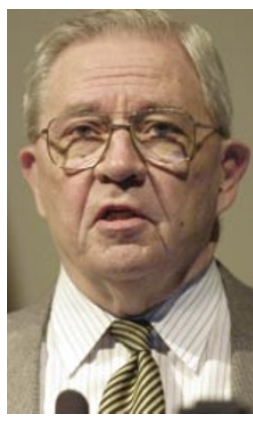

Donald Henderson: the search is on for a safer vaccine. Institute of Allergy and Infectious Diseases, which administers most civilian research in the United States related to diseases such as smallpox.

Fauci and others close to the immunization committee predict that it will continue to recommend against vaccinating the general public before a smallpox outbreak occurs, but that it is likely to suggest that vaccinations begin of tens of thousands of first responders who would have to investigate and contain a smallpox epidemic.

But experts differ on how widely the inoculation net should be thrown. "We have

\section{Senate adrift on cloning as talks break down}

\section{Erika Check, Washington}

Plans for the US Senate's long-awaited debate on the regulation of human cloning have collapsed, after negotiations between senators over the terms of the deliberation broke down on 13 June.

The breakdown means that prospects of any US federal legislation on cloning being passed this year are receding, with the Senate unable to muster the necessary 60-40 majority for either an outright ban on cloning or a more restricted ban, favoured by many researchers, that would permit 'therapeutic cloning' for research purposes.

The Senate's main advocate of an outright ban, Sam Brownback (Republican, Kansas), will now try to force his fellow lawmakers to address the issue by amending unrelated bills with pieces of his legislation.

This is the strategy that he used last year to force Tom Daschle (Democrat, South Dakota), the majority leader in the Senate, to promise a vote on cloning this year. But Daschle and Brownback were unable to agree on terms for the cloning debate.

Although Senate procedures are arcane, some observers say that Brownback's new strategy is unlikely to succeed, especially as it appears to lack support from leaders of his own party. "The best way to get anything done in the Senate is to have a structured agreement on how it will be discussed," says one lobbyist, adding that now "we have a free-for-all".

A procedural vote to kill Brownback's first attempted amendment, which would attach a ban on the patenting of cloning procedures to an antiterrorism bill, was scheduled for 18 June, as Nature went to press. Even if he loses it, the Kansas senator is expected to mount periodic attempts to attach a cloning ban to other bills. The House of Representatives has already backed a total ban on human cloning, which is supported by President George Bush. 
already vaccinated the groups that would go in and confirm a diagnosis, so it's a logical policy to extend that to people who are actually going to administer the vaccine if there is an outbreak," says Jonathan Tucker, director of the Chemical and Biological Weapons Nonproliferation Program at the Washington DC office of the Monterey Institute of International Studies.

The vaccine used to eradicate smallpox in the 1960s and 1970s was grown in cows, and the United States has about 77 million doses of this vaccine on hand. But 209 million doses are being prepared of a fresh vaccine that was grown in cell culture and has not been tested in large clinical trials.

"If you did it right, the trial would be large enough to learn what we need to know about the safety of the vaccine," says Anthony Robbins, chair of family medicine and community health at the Tufts University School of Medicine in Boston.

But not all public-health officials support this approach. Some argue that the risk of a smallpox attack does not justify exposing first responders to vaccine side-effects - vaccination causes serious side-effects in about 1 in 10,000 people. Others say that, given the hundreds of thousands of workers employed in health and emergency services in the United States, it is too hard to determine who should qualify for early vaccination.

"There is absolutely no end to the people who could justifiably be called first responders," says Alfred Sommer, dean of the Bloomberg School of Public Health at Johns Hopkins University in Baltimore, Maryland.

Donald Henderson, also at Johns Hopkins, a former adviser to the health secretary and leader of the global campaign that eradicated smallpox, says that the government is trying to develop a safer vaccine that could be used alone or in combination with the current vaccine. The three main candidates, he says, are the LC16m8 strain, which was given to 50,000 Japanese children in the mid-1970s; the modified vaccinia Ankara strain, which was developed in Germany in the 1960s; and a genetically engineered strain of the vaccinia virus.

After hearing the committee's advice, government officials will determine who gets the smallpox vaccine. Some politicians have already called for it to be made available to anyone who wants it. Scientists who fear the public-health consequences of such an approach will press the ACIP to issue very specific recommendations on who should receive the vaccine.

\section{'Dirty bomb' scare prompts clampdown on lab security}

\section{Rex Dalton, San Diego}

Universities in the United States are bracing themselves for a fresh security clampdown - on the way they handle radioactive materials used in research and medicine.

Pressure for greater security is set to grow after senior government officials said that Jose Padilla (also known as Abdullah al Mujahir), a terrorist suspect whose detention was announced on 10 June, had apparently intended to build a 'dirty bomb. "This man thought he could get the materials from places like university labs," said Paul Wolfowitz, the deputy defence secretary, in a television interview.

New calls for tighter control of radioactive materials are now expected - hot on the heels of a law that demands tighter strictures on biological agents that could be used by terrorists. University administrators are currently analysing the Public Health Security and Bioterrorism Preparedness Act, which became law on 12 June, to assess its impact on their institutions.

"There's going to be a flurry of proposals for legislation to secure materials," predicts Michael Levi, head of strategic security at the Federation of American Scientists. "I will be surprised if there aren't much stricter standards for universities," he says. Howard Garrison, a spokesman for the Federation of American Societies for Experimental Biology, agrees that regulations may well be tightened for labs using radioactive materials.

Experts say that most laboratory radioactive material, including the liquids used in various biological and medical tests, emits only microcuries of radiation, and would be ineffective as an exploded contaminant. But many labs also house medium-level radioactive sources, emitting up to 10 curies, which could cause low-level contamination over a wide area. Some also keep strong radioactive sources that emit hundreds or even thousands of curies.

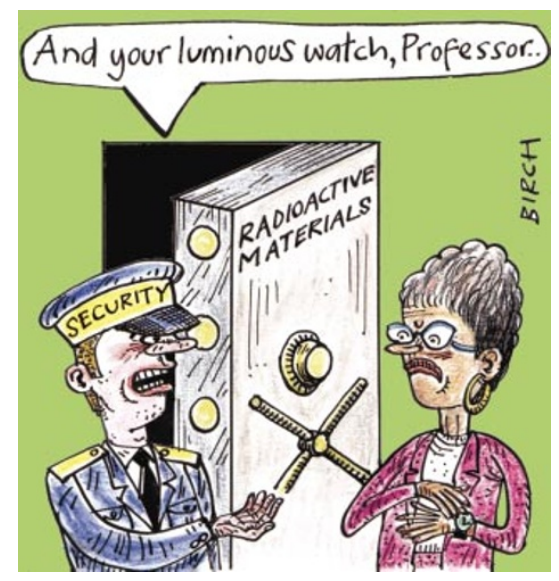

ॠ 2002 Nature Publishing Group

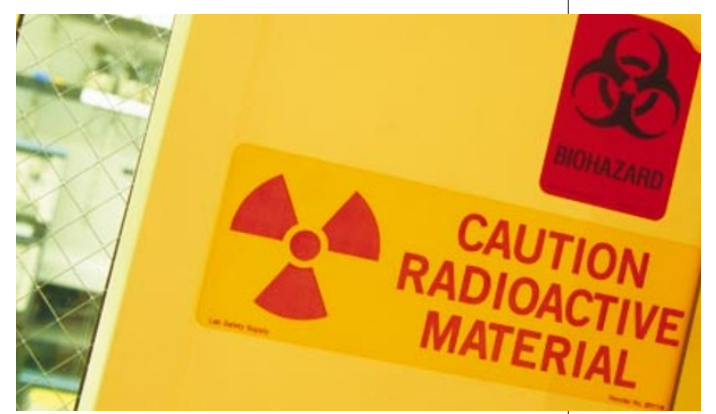

Warning sign: radioactive material is to come under closer guard across the United States.

Another possible source of highly radioactive material is the irradiator device - a heavily shielded, safe-like container containing cobalt-60 - that is used for research into food irradiation, among other purposes. But safety officers say that the theft of these machines is unlikely, as they are heavy and physically well-secured.

The Health Physics Society, a professional organization of radiation safety officers, held a discussion at its annual meeting this week in Tampa, Florida, on how best to address security problems without hampering research or health care, and has set up a task force to study the issue.

The Nuclear Regulatory Commission is responsible for licensing universities and other institutions to store radioactive materials, but it has signed agreements with 32 of the 50 US states to delegate the task to state governments. "All licensees received a written advisory after 11 September on heightened security," says John Hickey, chief of materials safety at the commission. "We are evaluating what improvements should be undertaken."

One issue that alarms Levi is the lack of government support for a project designed to retrieve highly radioactive material — much of it related to defunct nuclear research projects - from places that do not want it but cannot legally dispose of it.

In 1999, the Department of Energy (DOE) set up its Off-Site Source Recovery Project, at the Los Alamos National Laboratory in New Mexico, to carry out this task. But even though the project has identified material at more than 5,000 sites, both at universities and elsewhere, the DOE's budget proposal would cut its funding to $\$ 2.2$ million, from $\$ 3$ million this year and \$7 million last year.

The materials sought by the project are "a very likely source of radioactive material" for terrorists, Levi says. A DOE spokesman says that it will re-evaluate the project's funding in time for its next budget proposal. 